\title{
Identifying Factors Influencing Pre- Service Teacher Readiness to Use Technology During Professional Practice
}

\author{
Chantyclaire Tiba, Cape Peninsula University of Technology, Cape Town, South Africa \\ Janet Lesley Condy, Cape Peninsula University of Technology, Cape Town, South Africa
}

\begin{abstract}
Pre-service teachers should be taught how to use technology so that they are equipped to use the knowledge and skills acquired in their professional practice. However, studies have shown that preservice teachers are not adequately prepared to teach with technology. Therefore, the purpose of this study is to explore pre-service teachers' perspectives on factors that impact on their readiness to teach with technology. The TPACK and UTAUT2 models are used as frameworks. This is a qualitative study in which 16 pre-service teachers were involved in two focus group discussions, and the data obtained are deductively analysed. From the findings, a number of factors enabled and hindered teacher readiness to use technology. These factors include projects and workshops on technology, resources, and teacher-educators and mentor-teachers in schools modelling the use of technology. The study highlights the importance of consistent and effective modelling on the use of technology by teacher educators and mentor teachers in the schools in order to equip pre-service teachers to effectively teach with technology during professional practice.
\end{abstract}

\section{KEYWORDS}

Mentor Teachers at School, Modelling the Use of Technology, Pre-Service Training, Teacher Education Institutions, Teacher Educators, TPACK, Trainings on Technology, UTAUT2

\section{INTRODUCTION}

Today's learners are digital natives, as they were born after the advent of digital technology and they use technology, such as Instagram, Facebook, LinkedIn and Twitter (Swanepoel \& Bruwer, 2020), on a daily basis for communication and entertainment. Woo, White and Lai (2016) observe that many young people spend increasingly more time engaged in using technology devices in school, work and leisure activities. For learners to be prepared to successfully function in the 4th industrial era which is dominated by the use of technology (Mwapwele, Marais, Dlamini \& van Biljon, 2019), Teacher Education Institutions (TEIs) need to prepare pre-service teachers to effectively teach with technology. In response to this, in South Africa, the government has developed ICT policies such as the Minimum Requirements for Teacher Education Qualification (MRTEQ), to inform and foster the 
use of technology in TEIs. MRTEQ stipulates that pre-service teachers should know how to use ICTs for "innovative teaching and enhanced learning" (NDoHE, 2011, pp. 9). This policy document suggests that TEIs should create conditions that would develop pre-service teacher's ability and knowledge to effectively use technology, to improve on their quality of teaching and learning during professional practice. There is evidence in the literature which indicates that teachers who are knowledgeable and skilled in the use of technology, used it to transform their teaching and learning (Umugiraneza, Bansilal, North, 2018). This finding supports the argument made by Sabiri (2020) that learners will benefit more when technology is used constructively for curriculum delivery.

Due to the benefits of technology, there is a need for pre-service teachers to acquire the knowledge and skills to teach with technology during professional practice. Research has shown that pre-service teachers are not adequately prepared to teach with technology as the focus is on content: institutions have limited technology infrastructure, no plan and vision for technology integration and a lack of support from administration (Cuhadar, 2018; Davis \& Ariffin, 2013; Tiba, Condy, Chigona \& Tunjera, 2015; Valtonen, Kukkonen, Kontkanen, Makitalo-Siegl \& Sointu, 2017). It is against this background that researchers explore factors that influence pre-service teacher's readiness to use technology during professional practice. The researchers sought to answer the question:

What factors impact on pre-service teacher's readiness to teach with technology during professional practice?

The sample subjects employed for this study are final-year Intermediate Phase pre-service teachers at a university in the Western Cape, South Africa. These pre-service teachers were selected because they had been trained both on campus and during teaching practice at schools on how to use technology for teaching and learning. The pre-service teachers had workshop sessions and courses that trained them to use technology.

This study is significant since the findings contribute in creating awareness of the key factors that have an impact on pre-service teacher's readiness to use technology. Therefore, the Department of Higher Education, Science and Technology as well as TEIs, may consider the findings of this research and design ways to better prepare pre-service teachers to uptake and effectively use technology during professional practice. This is important because, in order for prepare pre-service teachers to effectively teach in the $21^{\text {st }}$ century classroom which is technology-driven, the starting point should be the TEI, as teachers cannot give what they do not have.

\section{THE TPACK AND UTAUT2 FRAMEWORKS}

The Technology Pedagogy and Content Knowledge (TPACK) framework guided this study (Mishra \& Koehler, 2006). According to Mishra and Koehler (2006), effective teaching with technology requires a blend of technology, pedagogy and content knowledge (TPACK). They define content knowledge (CK) as a teacher's knowledge of the subject matter to be taught in the classroom; technology knowledge (TK) is a teacher's knowledge and ability to use a variety of technologies for teaching and learning; and pedagogical knowledge (PK) covers knowledge of applying different strategies and teaching approaches during teaching. The intersection between TK, PK and CK produces pedagogy content knowledge (PCK), technology content knowledge (TCK), and technology pedagogy knowledge (TPK). PCK refers to knowledge of the most appropriate pedagogy to teach content; TCK is teachers' knowledge about technology that they can use to teach a particular content; and TPK is linked to a teacher's ability to choose the most appropriate pedagogy when teaching with technology. The concept of TPACK is diagrammatically represented in Figure 1.

As illustrated in Figure 1, TK, PK and CK intersect and overlap in the form of TPACK. According to Koehler, Mishra, Cain and Mishra (2013), all seven domains mentioned above form the basis of 


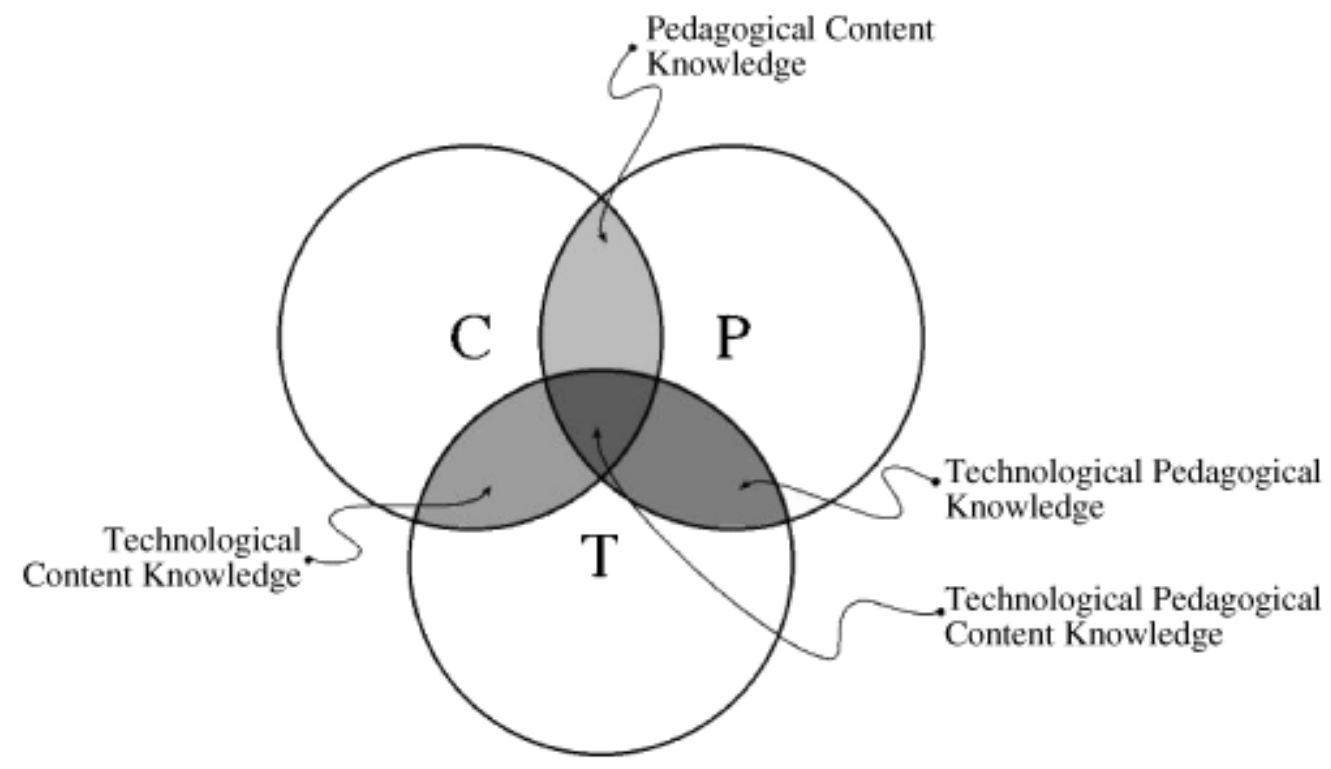

good teaching with technology. Since TPACK focuses on pedagogical issues, the researchers adopted the Unified Theory of Acceptance and Use of Technology 2 [UTAUT2] (Venkatesh, Thong \& Xu, 2012) model to further explore social issues that had an impact on pre-service teacher's readiness to use technology.

According to Ventekesh et al. (2012), seven factors influence an individual to use technology. These factors have been conceptualised in this study, and include: (i) 'performance expectancy' which is the benefits of teachers using technology for teaching and learning; (ii) 'effort expectancy' is the ease of using a particular technology; (iii) 'social influence' refers to the influence of others in encouraging teachers use of technology; (iv) 'facilitating conditions' refers to infrastructure put in place by schools to support teachers' use of technology; (v) 'hedonic motivation' is related to the enjoyment derived from teachers using a particular technology; (vi) 'price value' is the personal cost incurred by teachers when using technology, and (vii) 'habit' links to prior experiences of using technology which encouraged teachers to now use technology for curriculum delivery.

The researchers used the TPACK model as a framework, extended with the UTAUT2 model to collect comprehensive data on both pedagogical and social factors that had an impact on final-year pre-service teachers' readiness to use technology during professional practice.

\section{OVERVIEW OF LITERATURE REVIEW}

The following sections provide an overview of literature in relation to factors that had an impact on pre-service teachers' readiness to use technology during professional practice.

Teacher Education Institutions (TEIs) are supposed to provide technology to support teacher educators to use technology. However, in studies by Admiraal, van Vugt, Kranenburg, Koster, Smit, Weijers and Lockhorst (2017), Chaaban and Moloney (2016) and Cuhadar (2018), it was revealed that some universities which they based their studies on, did not support the use of technology; as some participants indicated that there was insufficient infrastructure. Regarding limited technology in TEIs, Chaaban and Moloney (2016) recommended that TEIs should offer a variety of technology that to be used in schools during professional practice, available and accessible. This provision increases 
the possibility for pre-service teachers to use these technologies during professional practice if it is available in their schools. This finding links the factor of 'facilitating conditions' as addressed by the UTAUT2 model, which highlights the importance of the availability of adequate resources and support in the uptake and use of technology (Venkatesh et al. 2012).

Another determining factor to pre-service teacher's readiness to use technology is training. In a study by Handler and Pigott (1995), the majority (81\%) of pre-service teachers felt prepared to use technology because they had courses on the use of computer and other technologies. Training in technology promotes its uptake as using technology becomes easy. This links to the concept 'ease of use' of the UTAUT2 model which indicates that an individual will use technology when less effort is required to use it (Venketesh et al., 2012). DiBella, Williams and Glover (2015) investigated the impact that a workshop training session had on pre-service teachers' teaching practice. The findings suggested that hands-on activities were the most beneficial in preparing pre-service teachers to use technology during teaching practice. They further indicated that hands-on training is important in equipping future teachers to mitigate challenges when using technology. When pre-service teachers were given hands-on project-based tasks in a study, which evaluated two courses on the importance of teaching in an authentic manner, it was revealed that pre-service teachers learned by trying techniques they could use when they teach with technology (Admiraal et al., 2017). A pre-service teacher in a study conducted by Batane and Ngwako (2017) indicated that teachers were competent because on campus they were taught how to use technology and given the opportunity to practise how to use it in the lessons as they prepared lesson plans and made presentations. These findings seem to confirm the constructivist belief that people learn best and acquire knowledge permanently by being interactive (Piaget, 1972) rather than watching the instructor demonstrate how a technology is used. However, Jita (2018) found that some teachers had no computer courses during pre-service training and they had to learn the technology skills on their own. When teachers do not acquire sufficient skills, even with resources, they will resist the use of technology (Chigona \& Chigona, 2010).

Mentors at schools during teaching practice play an important role in equipping pre-service teachers with skills needed to teach with technology. In a study by Admiraal et al. (2017), pre-service teachers acknowledged the importance of teaching practice in developing their technology knowledge and skills. This is reflective of the factor of social influence as presented by the UTAUT2 model, which explains how interaction with knowledgeable others is influential in the use of technology. However, Jita (2018) found that some pre-service teachers did not have positive experiences as the schools at which they were placed during teaching practice lacked resources. Similarly, in a study by Batane and Ngwako (2017) in which the researchers used observations, interviews and document analysis, to explore technology use by pre-service teachers during teaching practice, it was revealed that some mentors did not use technology. It was concluded in the study that pre-service teachers were not asked during assessment about technology as there was no specific item to evaluate the use of technology. This omission discouraged them from using technology during teaching practice. This study implies that using technology was not worth the effort as pre-service teachers were not marked on technology use during teaching practice. This finding is similar to that made by Chaaban and Moloney (2016) in which it was revealed that there were no formal requirements for mentor teachers to integrate technology during student teachers' field placements.

Pre-service teachers' experiences with teacher educators at the university contribute in preparing them to use technology during professional practice (Admiraal et al., 2017). Gill and Dalgarno (2008) highlight the importance of teacher-educators modelling the use of technology, as a significant factor in preparing teachers to use technology. In a more recent study by Baran, Bilici, Sari and Tondeur (2019) which investigated the impact of teacher education strategies on pre-service teachers' TPACK, it was shown that modelling was the most common strategy used by teacher educators. On the issue of modelling, courses were offered which some pre-service teachers acknowledged had an impact on their understanding of how to blend technology, pedagogy and content knowledge (İşler \& Yıldırım, 2018). Hence, some teachers in İşler and Yıldırım's study were motivated and eager to learn more 
about technology they could integrate during teaching practice. However, Handler and Pigott (1995) and Chaaban and Moloney (2016) found that some teacher educators lacked the skills to effectively model how pre-service teachers can achieve constructivist learning outcomes when they teach with technology. In some cases, it was reported that teacher educators on campus and mentor teachers at schools, generally were interested in content (İşler \& Yıldırım, 2018), not knowledge of technology. This report therefore implies that pre-service-teachers will lack the knowledge to be able to prepare a technology-assisted lesson.

\section{METHODOLOGY}

The question guiding this research is: what factors impact on pre-service teacher's readiness to teach with technology during professional practice? To answer this research question, a qualitative approach was used involving an interpretive paradigm. This is because the researchers intended to collect indepth data that would answer the research question (Smith \& Osborn, 2008).

The researchers used elements of purposive and convenience sampling. The target population consisted of Intermediate Phase pre-service teachers who were in their fourth-year at a TEI in the Western Cape, South Africa. These pre-service teachers were purposively chosen because they were in their final year, so it is believed they have acquired technology, pedagogy and content knowledge. With purposive sampling, the participants were knowledgeable about the topic (Arthur, Waring, Coe \& Hedges, 2012). Due to logistical constraints, the researchers selected a TEI which was within a $60 \mathrm{KM}$ radius of where they worked and lived. It was therefore convenient for the researchers and the pre-service teachers participating in the study (Farrokhi \& Mahmoudi-Hamidabad, 2012). The preservice teachers were trained for four years in order for them to acquire their Bachelor in Education (BEd) degree. During the four years, the pre-service teachers were being trained on campus and at schools during teaching practice. On campus, pre-service teachers are expected to acquire content, pedagogy and technological knowledge from teacher educators. During teaching practice with mentors, teachers put into practice what they have learned on campus. The contact details of all 110 final year Intermediate Phase (IP) pre-service teachers were taken from the Faculty office at the university. These teachers were invited via email and telephonically. 16 voluntarily accepted to be part of this study.

Considering the nature of the research question, which intends to seek final year pre-service teachers' perspectives on factors that have an impact on their readiness to teach with technology during professional practice, the researchers conducted two focus group interviews with 16 preservice teachers. All 16 pre-service teachers were interviewed using a semi-structured interview schedule. The semi-structured interview schedule consisted of three sets of questions. The first set of questions was introductory - to introduce and make the teachers comfortable and interested in the interview. These questions were straightforward and easy to respond to. These teachers were asked questions about the phase they were currently at, and whether they were exposed to using technology during teaching practice on campus, and which technology did teacher educators and mentor teachers frequently use for teaching and learning. The second set of questions was explorative as it focused on the main issue which is pre-service teacher's experiences with technology throughout their four-years training. These questions were the core of the study. The researchers asked questions such as: What are your views on factors on campus that had an impact on your readiness to use technology during professional practice? What are your views on factors during teaching practice that had impact on your readiness to use technology during professional practice? How confident are you in your ability to use technology during professional practice? The last set which is exit questions, were to conclude the interview and check with the participants if they wanted to add more information or anything had been missed. The teachers were asked questions such as: Suppose you have a minute to talk to the TEI on this topic, what would you say? Are there any other issues that have not been discussed that you feel are important and relevant? The interview questions were sent to the teachers before 
the focus group discussion for them to familiarise themselves with the questions. Each focus group interviews lasted for about 1 hour 30 minutes.

The recorded focus group interview was transcribed (Bless, Higson-Smith \& Sithole, 2013). The researchers independently read through the transcribed documents on the computer and assigned codes using different colours, to issues discussed that related to the research question of this study. Similar codes were converted into themes. After developing themes, the researchers met to discuss the themes that emerged and reached consensus about three themes. These themes were presented in the findings and discussion section, linking the literature and constructs of the TPACK and UTAUT2 frameworks in the form of deductive analysis.

To achieve trustworthiness, the interview schedule was sent to all researchers who coauthored this paper by email for suggestions and comments. Some of the questions were modified and re-phrased for clarity. All the researchers agreed that the questions on the interview schedule would solicit data on pre-service teachers' experiences with technology during preservice training. Permission to conduct research was sought from the TEI Ethics Committee as they grant researchers authority to conduct research in the university. Furthermore, permission was sought from the pre-service teachers who were participants in this study and they signed a consent form agreeing to participate in this study (Bloor \& Wood, 2006; Bless et al., 2013). The pre-service teachers who accepted to be interviewed were given pseudonyms to ensure confidentiality and anonymity.

\section{FINDINGS AND DISCUSSION}

This study sets out to identify factors influencing pre-service teacher's readiness to use technology during professional practice. The TPACK and UTAUT2 models were used as an analytical framework, to understand issues raised by the pre-service teachers in this study. The researchers analysed, interpreted and discussed the results in relation to the TPACK and UTAUT2 constructs. The findings revealed the following three themes:

1. Projects and workshops on technology;

2. Resources; and

3. Modelling the use of technology by teacher-educators and mentor-teachers at schools.

These three themes will be discussed in the following section.

\section{Projects and Workshops on Technology}

Some teacher educators at the university gave pre-service teachers projects that required them to use technology to complete their tasks. For example, the pre-service teachers mentioned the digital storytelling project, which is a creative project that required them to use text and digital tools to tell their stories on any social issue of their choice. The pre-service teachers had to blend text, videos, audios and images when developing their digital stories. The final stories were presented to the class for feedback and marked by the teacher educator. Two advantages of the group project-based task, as mentioned by two pre-service teachers, were that they acquired technological skills and worked collaboratively in a low-threatening environment, as they assisted each other to complete the task set. They reported:

We did the digital storytelling project in the fourth year which was huge. We were shown by our lecturers and facilitators how to summarise a text, use the computer, download, search for copyrighted photos and we made original music... (Teacher 5) 
... the lecturer divided us in groups of four to choose a Geography subject matter that interest us and do a project on it. It was a flexible environment where we did our own things and we had facilitators and our lecturer who guided us. (Teacher 1)

From these excerpts, it is clear that pre-service teachers were active rather than passive recipients of knowledge as they drove their own learning with the guidance of the teacher-educator and facilitators. This finding aligns with the constructivist belief that effective learning takes place when learners take responsibility for their own learning by constructing knowledge and making decisions on what needs to be included in their technology task (Piaget, 1972). In a study by İşler and Yıldırım (2018), pre-service teachers held courses in which they prepared digital materials. The pre-service teachers acknowledged that the courses were valuable, as they taught them how to constructively teach with technology. Similarly, Chaaban and Moloney (2016) report that the teacher educators in the five universities under study, gave pre-service teachers authentic tasks. For example, at one university, the teacher educator gave learners projects that required them to use technology tools to map out solutions to any educational problem. This hands-on approach enabled pre-service teachers to acquire knowledge and skills required for them to effectively teach with technology.

In this current study, technology training workshops on campus equipped pre-service teachers with skills needed during their professional practice. The pre-service teachers indicated that over the four years, they had sporadic ICT workshops on campus, at least twice a year which taught them how to use the smartboard and operate the computer. One pre-service teacher explained:

I am confident with using technology because we had workshops ... one or two times a year since I came to varsity, I think. Experts were invited to train us on how to use the smartboard, computer and software programs such as Microsoft. (Teacher 16)

The findings revealed that the TEI had organised workshop sessions to train teachers on how to use technology over the four years of their BEd degree. Consistent with these findings, Handler and Pigott (1995) found that the majority of pre-service teachers felt prepared to use technology because of the introductory computer courses they had received from their TEI. The pre-service teachers acknowledged that the workshops were of great value and equipped them to use technology. This finding can be linked to the concept of 'ease of use' of the UTAUT2 (Venkatesh et al., 2012) model: pre-service teachers are more likely to use technology if they have been trained. So less effort is needed to prepare and teach with technology during professional practice.

Other teachers felt that the workshops on campus did not sufficiently prepare them to teach with technology, as the duration of the workshops ranged between three to five hours which was not enough to upskill them to use technology. On this issue, a pre-service teacher remarked:

... sometimes these workshops ran for three to five hours, there was no time to play and manipulate the computer. I learn better when I practice and make mistakes and then asked for clarifications from the trainer you know. (Teacher 10)

One can infer from this finding that the pre-service teachers were not given an opportunity to practise the skills they had learned during the workshops. If teachers are not competent, confident and comfortable using technology, they may resist using it during professional practice. For example, in Chigona and Chigona (2010) it was apparent that, although there were technological resources available in the schools, in-service teachers resisted using technology because they were not skilled in its use.

All pre-service teachers unanimously agreed that training mostly focused on how to operate a variety of technology equipment, both hardware and software programs. A pre-service teacher noted: 
... for example, we were shown how to use smartboard, but how do I integrate it to teach content. I struggled with that. Yes, I have the technology knowledge but not how to blend it with content and pedagogy. (Teacher 9)

Many responses from the two focus group interviews conducted indicate that the workshops focused on technology proficiency, rather than on how to teach content, using appropriate pedagogical strategies and technology. This implies that teachers may find difficulty transferring the knowledge which they have learned into their classroom as effective teaching with technology requires a blend of technology, pedagogy and content (Mishra \& Koehler, 2006). Similar to this finding, Chaaban and Moloney (2016) and İşler and Yıldırım (2018) reported that ICT workshops did not give some teachers enough skills to be able to blend technology, pedagogy and content. The finding suggests that pre-service teachers had technology, pedagogy and content knowledge all in isolation.

\section{Resources}

The TEI provided infrastructure to support both teacher educators and pre-service teachers, in their use of technology. These infrastructures include: technology hardware and software programs and employing IT support personnel.

When pre-service teachers were asked during the two focus group interviews about technology available and accessible at their TEI, they mentioned: 'projectors', 'computer laboratory', 'internet', 'laptops', 'printers' and 'software programs' such as 'Readers and Leaders'. When probed, the majority of the teachers went further to indicate that the plugs installed on campus made it possible for them to use their personal laptops as they could charge them at any time.

A number of responses indicated that the university provided IT support to both teacher-educators and pre-service teachers. They used phrases such as "... the IT guys supported us in the labs (Teacher 2)”, “... the IT guys set up our passwords which makes it possible for us to access the computers and internet (Teacher 4)" “... another thing is that they assisted the lecturers to set up technological facilities before a lesson and in case any equipment broke down during classes, they promptly fixed it (Teacher 7)". Similarly, in Chaaban and Moloney (2016), the technical support was an important enabler for teachers' use of technology. The technical personnel assisted both the teacher educators and pre-service teachers when they faced problems, and the technical department was responsible for training teachers about technology.

On the basis of the above findings, it seems that the university has provided infrastructure which encouraged both teacher educators and pre-service teachers to adopt and use technology. These findings link the concept of 'facilitating conditions' of the UTAUT2 model as teachers used technology because of facilities provided by the university. Availability and accessibility of technology were a significant factor in encouraging teacher educators and in skilling pre-service teachers in the use of technology. The findings of this study highlight an important point which is consistent with the literature, that teachers will be more willing to use technology for curriculum delivery when technical personnel respond promptly to technical problems without them losing instructional time (Francom, 2016; Mueller \& Wood, 2012). Chigona, Chigona and Davids (2014) confirm that, without readily available support, teachers are reluctant to use technology in their teaching and learning since simple technical problems take too much time to be resolved.

Evidence from some pre-service teachers' responses shows that the computer laboratory on campus could not cater for an entire class. To exacerbate the situation, some of the computers in the laboratory were not functional as software programs were not updated. Comments from two preservice teachers explained this point:

Though we have five computer labs which could be a motivation, three labs were used for teaching by lecturers, with only two which could be used by students. Some of the computers were not working properly. (Teacher 15) 
... We have limited amount of computers that are working. So if it is not the computer that is not working, it is the internet connectivity which is slow. (Teacher 8)

Although there were technological facilities on campus, it appears that pre-service teachers and teacher educators faced challenges making optimal use of it. These challenges are important to address, since availability and accessibility of technology hardware and software programs may increase the possibility of teacher educators using it during teaching and learning; equipping pre-service teachers in the use of technology. The finding links with Batane and Ngwako (2017) which indicated that the computer laboratory was reserved for ICT classes; leaving limited allowance for other subjects to use it. This highlights that even when available, administrative measures can restrict the use of technology infrastructure in teaching. Some teachers in a study by Batane and Ngwako (2017) further indicated that there was lack of infrastructure such as projectors, computers, and teaching rooms were not conducive to learning. Similarly, Gill and Dalgarno (2008) and İşler and Yıldırım (2018) agree that pre-service teachers mentioned technical problems, insufficient access to internet and hardware as barriers to their readiness to use technology.

\section{Modelling Teaching With Technology}

By using technology during teaching, teacher educators on campus and mentor teachers at school model how technology could be used for curriculum delivery for pre-service teachers. It was reported that some of the teacher educators incorporated technologies that were already available at the university for teaching and learning. From watching the teacher-educator use these technologies to teach subject matter, pre-service teachers learned how to teach the same way during their professional practice. Two teachers from the focus group discussion expressed this point:

Some of our lecturers use technology during teaching. The best is that you can see how they have used it to teach a particular subject matter, so I can do the same in my class and why not better. (Teacher 1) Sometime a teacher will use a simple video to explain a concept. If I am teaching the same topic, I will use the same video. By lecturers using videos, they gave us an awareness of appropriate technology, video one can use to teach a topic. (Teacher 6)

The result indicates that pre-service teachers may be able to use technology during professional practice based on their experiences with teacher educators in the university. This indication links the belief that teachers teach the way they were taught. This could mean that, if teacher-educators cannot teach creatively with technology, pre-service may not be able to do so during professional practice as some of them may imitate what they have learned in the university with little or no improvement. This difficulty calls for improved training of teacher educators in order for them to be able to blend technology, pedagogy and content knowledge when they teach. Good teaching with technology requires a blend of these three knowledges (Mishra \& Koehler, 2006). Studies in the literature have emphasised that pre-service teachers learn how to use technology from teacher educators on campus and mentor teachers in the schools (Batane \& Ngwako, 2017; Gill \& Dalgarno, 2008; Handler \& Pigott, 1995; İşler and Yıldırım, 2018). The concept of modelling reflects the UTAUT2 factor of 'social influence': the pre-service teachers are motivated to use technology by seeing the teacher educators use it.

Similar to this finding were studies by Batane and Ngwako (2017) and İşler and Yıldırım (2018) that reported that some mentor teachers did not use technology, as the focus was on content. The majority of pre-service teachers indicate that during teaching practice, some of the mentor teachers did not use technology despite the fact that in some cases the technology equipment was available and accessible. According to a pre-service teacher, these teachers were old, so were probably not trained to use technology. One of the pre-service teachers reported that: 
I have been to schools were there was technology, but some of the teachers did not use it to teach subject matter, because they could not use it. These teachers were closer to retirement age. (Teacher 10)

It appears that some mentor teachers in schools did not use technology equipment available at the school because they were not proficient. A teacher commented:

I notice that all the old teachers in a school which I did my teaching practice during the third year were not interested in technology. They were not interested in learning from us, we were three student teachers in that school. I think they lost the interest because they were old and do not have the passion to learn new skills. (Teacher 12)

Other pre-service teachers complained about technology that was not readily available in quintile one, two and three schools. These schools were located in low socio-economic areas where parents do not pay fees and depend on the government for financial support:

The teaching practice co-ordinator allocated us to schools which did not have technological resources. In my second year, I was at a township school which lacked resources-the school still have prefabricated building. It was difficult and even impossible to learn how to use technology as there was just no resources. They lacked simple things like plugs and cables. (Teacher 15)

These findings are linked to the concept of 'facilitating conditions' of the UTAUT2 model: both teacher educators and mentors at schools were not provided with technology equipment which could facilitate their use for curriculum delivery. This suggests that pre-service teachers may struggle to use technology during professional practice because they are not skilled to do so. The lack of resources affects teachers' acquisition of technology.

Teaching with technology takes time: time to prepare and teach with the technology. During teaching practice, the pre-service teachers mentioned that they were not given an extra mark because they had put in effort to use technology, which discouraged them from integrating technology during curriculum delivery in the schools. They made statements such as:

... they (teacher educators or mentor teachers) do not care whether we use technology or not. (Teacher 6)

... they saw technology in the classroom, but did not ask me why am not integrating it into my teaching. (Teacher 4)

... there is no difference, whether I use technology or not. So why bother to go an extra mile. (Teacher 11)

... what is the need of using technology when one will get the same marks as their peers. (Teacher 3)

As mentioned in the findings, pre-service teachers were discouraged from using technology during teaching practice since there were no criteria to evaluate them. The pre-service teachers were more concerned to pass their practical assessment than to spend time on developing a technology lesson which would not be graded. This finding is similar to that of Batane and Ngwako (2017): some pre-service teachers indicated that the university wanted them to use technology because they were trained on campus in courses on ICT, but during teaching practice they were not evaluated. As a result, the pre-service teachers indicated they prepared their lessons without including technology, as they had too many objectives to be covered within a limited time. 


\section{CONCLUSION}

The study focused on factors that had an impact on pre-service teachers' readiness to use technology during professional practice. From the findings, it was revealed that projects and workshops on technology equipped pre-service teachers to learn how to use technology in a low-threatening environment. Other factors were availability and accessibility of technology resources and IT personnel who promptly assisted teacher educators when faced with technical problems, and teacher educators at the university and mentor teachers in the schools who model the use of technology during curriculum delivery.

However, pre-service teachers highlighted challenges they faced: they mentioned that few teacher educators gave them project-based technological tasks, and that the workshops held on campus were inadequate to equip them to effectively teach with technology. Some schools which the pre-service teachers were sent to during teaching practice, lacked resources to support their use of technology and were therefore not able to exercise their TK. Another factor that constrained their use of technology was that the teacher educators and mentor teachers in the schools did not give them more marks when they used technology. This discouraged them from using it for teaching and learning, as it required time to prepare and teach with technology. From these findings, the researchers conclude that preservice teacher's readiness to use technology will need urgent attention, if they are expected to adopt, adapt and teach effectively during professional practice.

From the findings, it is important for the university to focus on training teacher educators to effectively teach with technology, since pre-service teachers depend upon them to acquire knowledge that will be required to blend technology, pedagogy and content knowledge during professional practice. The training should focus on authentic, hands-on tasks that develop pre-service teachers' ability to constructively teach with technology.

Since these pre-service teachers will be teaching learners who are technology-driven, it is recommended that the TEI where this study was conducted and other similar TEI should include technology as part of the evaluation criteria. If a school has technological resources, pre-service teachers should be able to use it in an integrated way by blending the technology, pedagogy and content knowledge.

Some of the pre-service teachers who were assigned to quintile one, two and three schools, which lacked resources to support teachers' use of technology, were not exposed to technology. As a result, it is recommended that the TEI should allocate teachers to both resourced and non-resourced schools throughout their four years of training in order for them to have equal opportunities and rich experiences with technology.

Data from this study were collected from 16 final year pre-service teachers from one TEI. For more generalisation, the sample needs to be increased. Data were collected through interviews. To collect comprehensive data, future researchers need to use extensive data collection instruments such as questionnaire and observation schedule. Further research can be conducted from multiple universities to increase the overall knowledge and more insight on factors that influence pre-service teachers' readiness to use technology. This study was conducted at one university and with the intermediate phase pre-service teachers only. Future research could include Foundation Phase (FP) and Further Education Training (FET) pre-service teachers for a wider scope. Again, for more generalisation, other stakeholders such as administrators and teacher educators could be interviewed on their perspectives on pre-service teachers' readiness to use technology during professional practice.

This study identifies factors that have an influence on pre-service teachers' readiness to use technology during professional practice. The factors identified include: projects and workshops on technology, resources, and teacher-educators and mentor-teachers in schools modelling the use of technology. Future studies may consider the effectiveness of projects and workshops in adequately preparing teachers to teach with technology during professional practice.

\section{FUNDING AGENCY}

Open Access Funding for this article has been provided by Cape Peninsula University of Technology. 


\section{REFERENCES}

Admiraal, W., van Vugt, F., Kranenburg, F., Koster, B., Smit, B., Weijers, S., \& Lockhorst, D. (2017). Preparing pre-service teachers to integrate technology into K-12 instruction: Evaluation of a technology-infused approach. Technology, Pedagogy and Education, 26(1), 105-120. doi:10.1080/1475939X.2016.1163283

Arthur, J., Waring, M., Coe, R., \& Hedges, L. V. (2012). Research Methods and Methodologies in Education. Sage Publications.

Baran, E., Bilici, S. C., Sari, A. A., \& Tondeur, J. (2019). Investigation the impact of teacher education strategies. On pre-service teachers' TPACK. British Journal of Educational Technology, 50(1), 357-370. doi:10.1111/ bjet. 12565

Batane, T., \& Ngwako, A. (2017). Technology use by pre-service teachers during teaching practice: Are new teachers embracing technology right away in their first teaching experience? Australasian Journal of Educational Technology, 33(1), 48-61.

Bless, C., Higson-Smith, C., \& Sithole, S. L. (2013). Fundamentals of Social Research Methods: An African Perspective (5th ed.). Juta.

Bloor, M., \& Wood, F. (2006). Keywords in Qualitative Methods: A Vocabulary of Research Concepts. Sage Publications. doi:10.4135/9781849209403

Chaaban, Y., \& Moloney, R. (2016). Educating pre-service teachers in technology use: A study of provision at Lebanese universities. International Journal of Education, 8(2), 13-31. doi:10.5296/ije.v8i2.9188

Chigona, A., \& Chigona, W. (2010). An investigation of factors affecting the use of ICT for teaching in the Western Cape schools. Proceedings of 18th European Conference on Information Systems, 1-12.

Chigona, A., Chigona, W., \& Davids, Z. (2014). Educators' motivation on integration of ICTs into pedagogy: Case of disadvantaged areas. South African Journal of Education, 34(3), 1-8. doi:10.15700/201409161051

Cuhadar, C. (2018). Investigation of pre-service teachers' levels of readiness to technology integration in Education. Contemporary Educational Technology, 9(1), 61-75. doi:10.30935/cedtech/6211

DiBella, K., William, K. G., \& Glover, L. C. (2015). Improving pre-service teachers' readiness to integrate technology with cross-curricular adaptations. Journal of Education and Human Development, 2(1), 84-97. doi:10.15640/jehd.v4n2_1a9

Farrokhi, F., \& Mahmoudi-Hamidabad, A. (2012). Rethinking convenience sampling: Defining quality criteria. Theory and Practice in Language, 2(4), 784-792.

Francom, G. M. (2016). Barriers to technology use in large and small school districts. Journal of Information Technology Education, 15, 577-591. doi:10.28945/3596

Gill, L., \& Dalgarno, B. (2008). Influence on pre-service teachers' preparedness to use ICTs in the classroom. In Proceedings ASCILITE Melbourne 2008. Retrieved from http//www.ascilite.org

Handler, M. G., \& Pigott, T. (1995). Technology preparation for preservice teachers: do they feel prepared for the 21st century classrooms? World Conference on Computers in Education, 1.

İşler, C., \& Yıldırım, Ö. (2018). Perceptions of Turkish pre-service EFL teachers on Their Technological, Pedagogical Content Knowledge. Journal of Education and Future, 13, 145-160.

Jita, T. (2018). Exploring pre-service teachers' opportunities to learn to teach science with ICTs during teaching practice. Journal of Education, 71(71), 74-90. doi:10.17159/2520-9868/i71a05

Koehler, M. J., Mishra, P., \& Cain, W. (2013). What is technological pedagogical content (TPACK)? Journal of Education, 193(3), 13-19. doi:10.1177/002205741319300303

Koehler, M. J., Mishra, P., Cain, W., \& Mishra, P. (2013). What is Technology Pedagogy Content Knowledge. Journal of Education, 193(3), 13-19. doi:10.1177/002205741319300303

Mishra, P., \& Koehler, M. J. (2006). Technological pedagogical content knowledge: A framework for teacher knowledge. Teachers College Record, 108(6), 1017-1054. doi:10.1111/j.1467-9620.2006.00684.x 
Mueller, J., \& Wood, E. (2012). Patterns of beliefs, attitudes, and characteristics of teachers that influence computer integration. Education Research International, 2012, 1-13. https://www.hindawi.com/journals/ edri/2012/697357. doi:10.1155/2012/697357

Mwapwele, S. D., Marais, M., Dlamini, S., \& van Biljon, J. (2019). Teachers' ICT adoption in South African rural schools: A study of technology readiness and implications for the South Africa Connect broadband policy. The African Journal of Information and Communication, 24(24), 1-21. doi:10.23962/10539/28658

National Department of Higher Education and Training. (2011). Draft Policy on the Minimum Requirements for Teacher Education Qualifications selected from the Higher Education Qualifications Framework (HEQF). Retrieved from https://www.dhet.gov.za//Draft\%20Policy\%20on\%20minimum\%20requirements\%20for\%

Nordin, H., Davis, N., \& Ariffin, T. (2013). A case study of secondary pre-service teachers' Technological Pedagogical and Content Knowledge mastery level. In 13th International Educational Technology Conference. Sakarya University Turkey. doi:10.1016/j.sbspro.2013.10.300

Piaget, J. (1972). The psychology of the child. Basic Books.

Sabiri, K. A. (2020). ICT in EFL Teaching and Learning: A Systematic Literature Review. Contemporary Educational Technology, 11(2), 177-195.

Smith, J. A., \& Osborn, M. (2008). Interpretative phenomenological analysis. In J. A. Smith (Ed.), Qualitative psychology: a practical guide to research methods (2nd ed.). Sage Publications.

Smith, J. A., \& Osborn, M. (2008). Interpretative Phenomenological Analysis. In J. A. Smith (Ed.), Qualitative Psychology: A Practical Guide to Research methods (pp. 53-80). Sage.

Swanepoel, G. P., \& Bruwer, A. (2020). Educating the always-on generation in an instant(gram) \#blended learning. Perspectives in Education, 38(1), 16-29. doi:10.18820/2519593X/pie.v38i1.2

Tiba, C., Condy, J., Chigona, C., \& Tunjera, N. (2015). Digital storytelling as a tool for teaching: Perceptions of pre-service teachers. The Journal for Transdisciplinary Research in Southern Africa, 11(1), 82-97. doi:10.4102/ td.v11i1.33

Umugiraneza, O., Bansilal, S., \& North, D. (2018). Exploring teachers' use of technology in teaching and learning mathematics in KwaZulu-Natal schools. Pythagoras, 39(1).

Valtonen, T., Kukkonen, J., Kontkanen, S., Makitalo-Siegl, K., \& Sointu, E. (2017). Differences in pre-service teachers' knowledge and readiness to use ICT in education. Journal of Computer Assisted Learning, 34(2), 174-182. doi:10.1111/jcal.12225

Venkatesh, V., Thong, J. Y. L., \& Xu, X. (2012). Consumer acceptance and use of information technology: Extending the unified theory of acceptance and use of technology. Management Information Systems Quarterly, 36(1), 157-178. doi:10.2307/41410412

Woo, E. H. C., White, P., \& Lai, C. W. K. (2016). Impact of information and communication technology on child health. Journal of Paediatrics and Child Health, 52(6), 590-594. doi:10.1111/jpc.13181 PMID:27333844 